\title{
Unravelling of Waste in A Touristic Area of Pangandaran from Neglecting Towards Embracing Informal Waste Management Practices, West Java, Indonesia
}

\author{
BASTIAAN SCHIPPERS* and ANINDA PRATIWI \\ Leiden University, The Netherlands \\ Universitas Gadjah Mada, Indonesia \\ (*author for correspondence, email: Bastiaansamuel@gmail.com)
}

\begin{abstract}
Increased attention for sustainable waste management practices has in Indonesia resulted in legislation that seeks participation and self-regulation amongst people in urban and rural areas. However districts are trying to meet the expectations of the national government, implementing Westernized-recycling systems. We demonstrate that these top-down waste management practices as well as the current approach towards scavenging systems as being problematic and undesirable, will not lead to effective waste management. Using a holistic approach we explore the subjectivity of waste and alternating perceptions of these objects in both formal and informal waste management practices. Moreover this article considers the functioning of informal waste management systems to be dynamic and profitable. Within the context of a touristic area that can't keep up with the increasing amount of solid waste, this article advocates a highly potential informal waste management practices that are systematically overlooked.
\end{abstract}

Keywords: waste management, informal sector, scavenging, sustainable development, tourism.

\section{INTRODUCTION}

From the centre of Pangandaran it is only a short ride. A small road that has seen better days leads slightly upwards into a densely wooded area. The garbage dumb (hereafter TPA) covers about 10 acres and the sight of yellow trucks that come and go implies that this amount will expand rapidly. The unloading of the trucks is not only seen by us, a small group of scavengers is observing the process from inside their fabricated houses on the edge of the dump, patiently waiting to collect their recyclables.

Having observed a mixture of situations such as the one above, I am obliged to say that although this particular scene is most often situated in the local newspapers, it merely shows a glimpse of what waste management practices in Pangandaran looks like.

Towards the end of the $20^{\text {th }}$ century informal waste management practices (scavenging systems) had gained a lot of interest across the academic field (Sicular 1993; DiGregorio 1994). Scavengers where described as relatively poor, having a low ascribed social status and involved in a 'informal sector' as a response to chronic poverty in developing countries (Medina 2010).

The early years of the 21 th century provided us with research that successfully attempted to show the heterogeneity of scavenging throughout the world (Nas and Jaffe 2004; Wilson 2006). The basic premises of this argument is that scavenging can no longer be seen as separated from waste 
management as a whole, but as a flexible sector which under the right circumstances can integrate with formal waste management (Nas and Jaffe 2004).

Current research seems to validate that this potential has not been incorporated by national governments (Pasang 2007; Vergara and Tchobanoglous 2012). As a response to its vast expanding waste issues across the country, Indonesia has implemented a number of national projects such as PROPER, PROKASH and recently the $3 \mathrm{R}^{1}$ Program. Amongst other aspects, these programs are seeking for self-regulation, participation and environmental awareness amongst people in rural and urban areas. Also they often include the use of expensive machines to be placed near TPA's, attempting to decrease the waste mass.

It can be stated that the consensus academic view questions the outcome of these top down programs. Brown (1997) has argued that participation as such is likely to be an alliance between the local elites. Thomas (1999) criticises the unquestioning adoption of westerns systems standards, often not leading to sustainable practices. Adopting these systems, anthropologists claim the government still underpins a neo-liberal perception of scavenging as being, unhealthy and criminal, a sign of failure to modernize (Medina 2010). The lack of a much-desired modernity associated with these systems and individuals, seems to have mantled the existence of a complex informal waste management systems for to long.

Though academic studies on this captivating, but poorly assessed topic, have successfully emphasized an existing variety of scavenging and scavenging systems, the characteristics of waste as an object in waste management practices has remained remarkably free from empirical scrutiny. However, the notion of waste as an object gained ground in relation to dirt and pollution, which has led to the insight that waste should be assessed in the context of a process and place in which it gains or loses value. This deeper understanding draws on earlier research conducted by Douglas (2002) who stated that waste is a matter out of place. It is an element that easily shifts from being a desired object to an object that belongs in a residual category, rejected from our normal scheme of classifications (ibid.). In Gee's words:

Waste is a from of pollution, marked as such by having participated in a process; that process is one wherin substance stops being acceptable or even valuable and becomes unwanted or taboo [...] pollution then exists when as substance has crossed a border and becomes threatening to the system to which it no longer belongs (Gee 2010).

On these grounds we will argue that schemes of classifications are cultured and therefore different according to where possible waste objects are produced and consumed. Therefore a cultured perception of waste lies at the heart of the discussion on waste management practices in Indonesia. This view is very much in line with the premise that one man's waste can be another man's livelihood (Drackner, 2005). After conducting research in Peru, Drackner provides us with a valuable insight stating that a categorization of perceptions of waste could partly solve the misunderstanding that local communities will participate in waste management programs implemented by the government.

Seeking an anthropological approach on waste management practices, our case study in Pangandaran is an attempt to address the characteristics of waste as an object disposed, valued and traded by the community in which it circles.

Believing that only a holistic perspective on the matter would help us to situate and understand how waste is seen and regulated, we found that what is regarded as waste differs across the area, hence it is treated in different ways.

Second, we found that a inadequate formal waste management on local level and shortage of budget are the main reasons for a low level of service, consequently it can not provide a sustainable way which could decrease the amount of waste the touristic areas.

Furthermore, by following waste objects we found evidence that underpins informal waste management being a very independent and dynamic system that involves a trade route embedded in the local communities, leading far beyond the TPA practices outside the city. 
In other words, informal waste management has proven to be a very flexible and rewarding system that is not seen as having potential by local government. Not only the local bureaucratic elite is overlooking it, it is still considered as being problematic and undesirable. An odd conclusion, especially for a city that relies on domestic as well as foreign tourism and which openly flirts with the idea of becoming Bali 2.0.

\section{METHODS}

The results are based on ethnographic research on livelihood strategies of households and small businesses that took place between January and March 2014 in the context of a master's degree in Environment and Development on behalf of Leiden University and Gadjah Mada Universitas. Methods used in this study included semistructured interviewing, qualitative observation such as social mapping and transect walks. In addition we conducted quantitative studies based on 'following the waste', which included basically three stages: collection, transport and disposal of objects. Moreover, the sorting, transforming and exchanging the objects where observed at varying points along the way.

\section{PANGANDARAN}

In 1995 around 7400 people were living in Pangandaran desa in inhabiting 1675 households, covering a 5000 acres area. Although this community followed a mixed livelihood strategy consisting of fishing, shrimp farming and paid labour on coconut-plantations, the number of people working in the tourist sector grew rapidly. Whilst the East coast was used for perpetrating the fishing boats, the West coast served as a place for retail and the unloading of fishing boats, which besides the Tamul National Park over time became one of Pangandaran's first touristic attractions (Wilkinson \& Pratiwi, 1996).

In contrast of what has been situated as a beach resort in several tourist brochures throughout the last two decades, Pangandaran is dealing with several issues that where already thoroughly described by Wilkinson and Pratiwi in previous research:
'The change brought by tourism for the local people in Pangandaran can be understood only within the context of complex social and economic system of the village: the predominance of poverty, the lack of employment options, the topdown development policy, the lack of local political power, the class structure, and the local people's ideology of gender (1996: 295).'

Although there is insufficient current evidence that validates these matters and this casestudy is not an attempt in itself to support these assumptions, we found that these issues are very much alive in Pangandaran. An ambiguous claim on the land of RWs near Pantai Barat to build an airstrip, the forced relocation of hundreds of fisherman and an expanding area of prostitution, hidden but still very present along the coastline. These examples and the inevitable sight of poverty due to a lack of jobs show merely a glimpse of a complex social and economic system run by the local elite.

In order to understand what waste management issues this city is currently facing, we need first to understand that Pangandaran is going through an organizational transition. Not only the number of inhabitants has increased tremendously, since 2012 Pangandaran and its closely located subdesa are separated from kabupaten Ciamis, forming a new region named after its well-known coastal city. The desirable outcome of this change is an economic opportunity to spread-out a large sum of touristic money over a relatively small area. However, a well-organized waste-management system, one could expect in line with such high expectations, is not in place.

\section{DYNAMICS OF INFORMAL WASTE MANAGEMENT}

Following the 'life' of waste in Pangandaran, a range of different methods and techniques can be observed. Basically there are three stages: collection, transport and the disposal of objects. The sorting, transforming and exchanging of objects can be observed at varying points along the process. 
The methods of waste containment in households, hotels and warung-warung in Pangandaran include the use of the pick-up services by the cleaning department, Dinas Kerbersian Pangandaran (DKP). Modern collection vehicles (VIAR) are used to transport the waste to the TPS, before it is brought to the TPA, where limited recycling takes place by local tukang pemulung. However, because of poor infrastructure and the lack of pick-up services this method is only used in the touristic areas of Pangandaran. As a woman in Babakan (a more rural area of Pangandaran) explains:

'Even though we want to make use of the pick-up service, we can't because no truck can reach my house. Therefore the head of my town advices me to burn all my waste in the lombang.'

Secondly disposal takes place in ways such as the burning of waste in a lombang and landfilling at a vacant lot or along the roads and on the beach.

Thirdly one storages and pre-collect waste in or outside the property before selling valuable recyclables (hereafter rongsok) to tukang rongsok or pemulung. Based on their value, objects that are likely to transform into rongsok are; tin, cardboard, iron, copper and different forms of plastic glass. From here rongsok is being selected and exchanged between a range of storage sites in Pangandaran, which can be identified as tempat rongsok and tempat lapak. On these sites rongsok is carefully selected, weighed and stored, waiting to be sold for a fair price. Depending on what is in stock and a fluctuating oil price, the main transport costs, rongsok is often exchanged for other types before it sold to a for example a tempat penggilingan. On this site a carefully selection procedure is in place, used to identify valuable transparent plastic. This is followed by a process of cleaning and shredding before it can be sold to the highest bidder.

Prominent in informal waste management in Pangandaran is the remarkable thoughtfulness and carefulness when it comes to selecting and trading valuable objects. Besides it becomes clear that a range of different actors, are involved in a highly dynamic business, that works completely independent. This business, influenced by competition, a fluctuating price range and sustainable partnerships, starts with the collection of mainly household waste.

\section{BARRIERS TO FORMAL WASTE MANAGEMENT}

Until 2008 the RW's in kabupaten Ciamis were fully responsible for the collection of household waste, which was then transported to a TPS, designated by the DKP. This institution was appointed to arrange further transport to the TPA in Porbahaju. From 2008 onwards, according to the Pengolalaan sampah (no. 18/2008), stipulated by the national government, the DKP had to take responsibility for the implementation of a fully operational system that not only demanded collection of household waste, but also processing of the waste mass. Furthermore it stated a closure of open-dump sites such as the TPA within 5 years.

We are not alone in our view that five years later Pangandaran has not met the requirements given by the national government. On the basis of what is formally stated by the people working at the DKP, it seems fair to distinguish the following reasons for this failure:

- A shortage of budget to buy enough properly functioning waste-management equipment and to fill the Pagawai Negeri Pisil (PNS) positions.

- A large area of district Pangandaran is inaccessible, due to unpaved roads.

With regard to budget, since 2012 the DKP is responsible for the collection in a larger area, which cannot be covered with the current available equipment. As one of the man explains on February $12^{\text {th }} 2014$ :

'We are now responsible for 10 sub districts within district Pangandaran instead of 3 with little equipment. Due to tourism, there are only paved roads in Pangandaran (desa), which means we only collect waste here.'

The national government will only expand this budget when Pangandaran shows to be a potential independent district. This new budget is 
likely to be spend on new equipment, more PNSworkers and a plastik-kristal processor that will be placed on the TPA. Unfortunately besides these financial and logistic issues there is a deeper cause for these barriers not visible at first glance.

The DKP states that it will not make use of the existing labour, carried out by actors involved in informal waste management practices, because of its unreliable and dodgy characteristics. Instead it focuses on a new development project called Unit Pelaksana Teknis Daerah, which involves new machinery, which should decrease the amount of landfilling and the encouragement of tourists to litter at appropriate sites.

In principle, municipal collection workers have a PNS-status, which means that they earn a fair income as well as insurance. Once someone has received this position he/she is not likely to be fired. As stated by one of the informants on February $19^{\text {th }}$ :

'A PNS position gives someone status. Here it doesn't matter if this person does a good job in collecting waste or cleaning sites around Pangandaran. Often these people even ask a tip, kretek or kopi before threatening people not to collect their waste in the nearby future. It happens, we all know it. In the mean time very little waste is being picked up and people just hang around the office in their uniforms. Asal bapak senang - as long as the boss is happy.'

When we narrow down the available data, it seems fair to suggest that the absence of targets, equipment and a lack of working attitude are the main barriers to formal waste management in Pangandaran. Furthermore the attitude towards existing informal waste management practices as being unnecessary and unreliable leads to further segregation and misconceptions. Instead of embracing these methods, one aims to meet the expectations of the national government by implementing expensive techniques equal to existing informal practices.

\section{DISCUSSION}

At this point the discussion centers on the differences and similarities between two different types of waste management practices that seem to appear in Pangandaran.

When it comes to waste disposal, landfilling is essentially the cheapest way of getting rid of Pangandaran's city garbage, but regarding the inevitable sight of waste piling up along the riverbed, the roads, the beach and the bulging TPA, this becomes problematic considering the consequences for both the environment and public health. Furthermore, taking into account the ambitious touristic plans the district has planned, landfilling is seen as the biggest threat by all our informants.

Regarding the collection and transportation of waste, the methods used by the local authorities are lacking efficiency due to practical problems such as communication, finances and logistics. Also, participation of the people in Pangandaran appears particularly problematic, because of poor infrastructure and the lack of service. Instead of providing a solid pick up system, the DKP only focuses on the touristic areas.

Although the transportation of informal waste management practices relates to labor intensive collection methods such as manually pushed bikes with limited range, they seem to be more suitable than the capital intensive methods like the modern trucks used by the DKP. Firstly because they are inappropriate to the infrastructure of Pangandaran and secondly because of the lack of carefulness in which rongsok is being selected and exchanged.

This is due to a difference in perception of what waste includes. With regard to the production patterns in Indonesia, which focuses on one-day packages, the composition of waste shows a high proportion of plastic. The market for informal waste management in Pangandaran is therefore based on many different types of plastic, which are utterly identified as assets. Therefore the argument against the DKP practices is that they examine waste merely as a risk, as something that belongs in a dirty place, invisible for the eye. Moreover, when taking into account the poor attitude towards waste issues in their city, they regard waste as someone else's problem.

Following and analysing different actors along the 'life' of waste in both their selection and exchanging of rongsok, it becomes evident that 
the ambiguous assumptions expressed by the DKP are short-sighted as well as unjustified. Instead of relating trading rongsok (jual beli rongsok) to doing dirty and unreliable work, informants find themselves working in a clean and profitable business. As one of man explain:

\begin{abstract}
'Some people in Pangandaran still think my kind of work as a tukang rongsok is poor and dirty, but is not. I maintain healty and profitable relationships with my costumers based on thrust and mutual benefit. They know that what I do is useful for the community.'
\end{abstract}

On the basis of current evidence available it seems fair to suggest that informal waste management has proven the be a developed social and economic system, in which sustainable relationships, flexibility and hard work lead to profit.

\section{CONCLUSION}

Altogether, previous research done on scavenging and informal waste management systems is still very limited. One reason for the dearth of this particular research data is that it is regarded difficult and sometimes dangerous to conduct research in these often avoided communities. Another reason is that previous analyses regarding waste management issues in developing countries seem to focus more on increased participation in all layers of communities. Often throughout NGO developing programs, targeting self-regulation through education. To be able to broaden the empirical examination of scavenging dynamics, we argue that more research should be conducted on informal waste management, contextualized by the subjectivity of waste.

As shown in this case study, under the sway of existing negative perceptions informal waste management practices in Pangandaran are separated from waste management as a whole. This shows similarities with Ferguson's (1994) perception of local elite who sees 'the people' as a generalised mass who are constantly making the wrong decisions, and therefore exclude them from any development planning. It seems that the local government is reluctant to become involved in scavengers practices, because they see them as a failure to modernize.

On the contrary informal waste management practices in Pangandaran have shown to be a highly diverse community and well adapted to the local waste situation, influencing a recycling system that is flexible, efficient and thorough.

While recycling is generally the most environmentally consciousness and costeffective method of waste disposal, it is time for Pangandaran to shift the focus from neglecting towards embracing the potential of informal waste management practices.

\section{ACKNOWLEDGEMENT}

We thank Bart Barendregt for visiting the research site, commenting on our methods and questions. The research highly benefited from guidance by Tessa Minter and onsite advice and caretaking by Ahmad.

\section{ENDNOTE}

1 Declaration of Indonesian Movement for Waste Care (2014) The Ministry of Public Services and the Ministry of Environment have signed a resolution of the $3 \mathrm{R}$ program on February 24th 2014. http://wwww.thejarkartapost. com/news

\section{REFERENCES}

Brown, D. (1997) 'Professionalism, Participation and the Public Good: Issues of Arbitration in Development Management and the Image of the Neopopulist Approach' Paper presented to Conference on Public Sector Management, Manchester 19 -21 July.

Douglas, M. (2002) Purity and danger: An analysis of concepts of pollution and taboo. Cornwall: Routledge p. 3-45, 197.

DiGregorio (1994) 'Urban Harvest: Recycling as a Pesant Industry in Northern Vietnam' Occasional Paper 17: Honolulu: East-West Center 1.

Drackner, M. (2005) 'What is Waste? To Whom? An Anthropological Perspective on Garbage'. Waste Management Research 23: 175-181.

Ferguson, J. (1994) 'The Anti-politics Machine.' The Ecologist 24-5: 174.

Gee, S (2010) 'Making Waste: Leftovers and the 
Eighteenth-Century Imagination' Princeton University Press 9-10.

Medina, M. (2010) 'Solid Wastes, Poverty and the Environment in Developing Country Cities: Challenges and opportunities' World Institute for Development Economics Research 23: 8-11.

Nas, P. J., \& Jaffe, R. (2004) 'Informal Waste Management' Environment, Development and Sustainability 6-3: 337-353.

Pasang, H., Moore, G. A., \& Sitorus, G. (2007) 'Neighborhood-based Waste Management: A Solution For Solid Waste Problems In Jakarta, Indonesia' Waste Management 27-12: 24-38.

Sicular, D.T. (1993) Scavengers, Recyclers, and Solutions for Solid Waste Management in Indonesia Center for Southeast Asia Studies, University of California 84-172.
Thomas, C. (1997) 'Waste management and recycling in Romania: a case study of technology transfer in transition', Technovation 265-371.

Vergara, S. E., \& Tchobanoglous, G. (2012) 'Municipal Solid Waste and the Environment: A Global Perspective' Annual Review of Environment and Resources 37: 277-309.

Wilkinson, F. \& W. Pratiwi (1995) 'Gender and Tourism in an Indonesian Village' Annals of Tourism Research 22-2: 283-299

Wilson ,D.C., Velis \& C. Cheeseman (2006) 'Role of Informal Sector Recycling in Waste Management in Developing Countries' Habitat International 30-4: 797-808. 